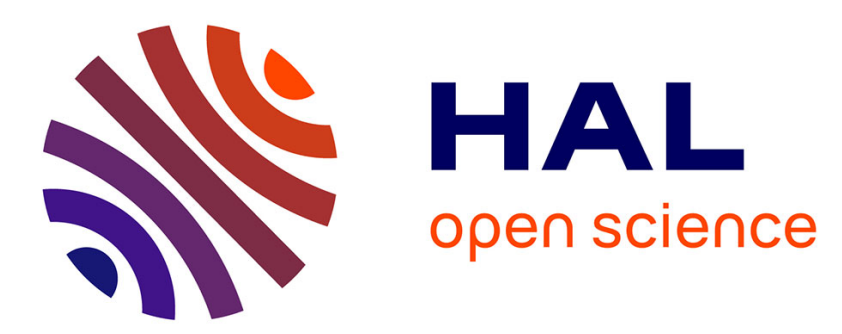

\title{
The implementation of elder-care in France and Sweden: a macro and micro perspective
}

\author{
Ingrid Jönsson, Anne-Marie Daune-Richard, Sophie Odena, Magnus Ring
}

\section{To cite this version:}

Ingrid Jönsson, Anne-Marie Daune-Richard, Sophie Odena, Magnus Ring. The implementation of elder-care in France and Sweden: a macro and micro perspective. Ageing and Society, 2011, 31, Published online: 18 janvier 2011; Sous presse (20 p.). 10.1017/S0144686X10001327 . halshs-00573184

\section{HAL Id: halshs-00573184 \\ https://shs.hal.science/halshs-00573184}

Submitted on 3 Mar 2013

HAL is a multi-disciplinary open access archive for the deposit and dissemination of scientific research documents, whether they are published or not. The documents may come from teaching and research institutions in France or abroad, or from public or private research centers.
L'archive ouverte pluridisciplinaire HAL, est destinée au dépôt et à la diffusion de documents scientifiques de niveau recherche, publiés ou non, émanant des établissements d'enseignement et de recherche français ou étrangers, des laboratoires publics ou privés. 


\title{
The implementation of elder-care in France and Sweden: a macro and micro perspective
}

\author{
INGRID JÖNSSON*, ANNE-MARIE DAUNE-RICHARD†, \\ SOPHIE ODENA $\dagger$ and MAGNUS RING*
}

\begin{abstract}
This paper presents results from a comparative project on the implementation of elder-care in France and Sweden. The transition to requiring care is understood as a process, and elder-care is seen as a part of a more general organisation of social care that reflects different welfare traditions. An overview of elder-care on the institutional level in the two countries is supplemented by case studies from the perspective of older people which identify ways of co-operation between actors, such as public eldercare providers, family members and help provided by profit and non-profit organisations. The interviews include approximately 20 older persons in each country as well as a small number of administrators and adult children. The study sheds light on how policies are implemented on the local level and puts the focus on who actually does what and when for older persons with care needs. The different roles played by the state, the family, the market and civil society are examined. Family members in France take on a more active role both as co-ordinators of care and as actual caregivers. The study shows that gender and social class remain associated with caring but that such differences are much larger in France than in Sweden.
\end{abstract}

KEY WORDS - elder-care, welfare tradition, class, gender.

\section{Introduction}

Current demographic trends have put the issue of the care of older people on the political agenda in most European countries. Demographic changes, such as decreasing fertility and mortality rates and increasing longevity, coupled with changes in family structures, in social protection systems and in value systems are all important factors for the possibility to receive the help and support needed in old age. Elder-care is part of the organisation of social care in society, which can be defined as 'the activities and

* Department of Sociology, Lund University, Sweden.

$\dagger$ Laboratoire d'Economie et de Sociologie du Travail, GNRS, Université d'AixMarseille, France. 
relations involved in meeting physical and emotional requirements of dependent adults and children, and the normative, economic and social frameworks within which these are assigned and carried out' (Daly and Lewis 2000: 285). According to this definition, social care covers the relationships between diverse sources of financing, provision, organisation and social relations at different levels of society. Economic and social frameworks reflect different welfare traditions, where the state, the market, the family or civil society play different roles. Defining elder-care in this way is also useful for tracing changes at the macro level in society as well as for identifying the implication of such changes on the micro level, i.e. in everyday life (Daly and Lewis 2000).

This analytical approach was applied in a comparative project undertaken in 2007 and 2008 in Sweden and France to study access to social care when older persons become dependent. ${ }^{1}$ The aim of the project was to study with an explorative approach the entrance into dependence as a process, i.e. how the need of help and support of elderly persons over time is attended to (or not) and by whom. In doing so we tried to identify everyday experiences among elderly persons in the two countries, especially their interaction with the welfare systems.

Starting from an elderly person's experience of becoming dependent and receiving help sheds light on how policies are implemented at the local level and puts the focus on who actually does what and when. Comparisons limited to the institutional level often underestimate the importance of the organisation of elder-care at the local level (e.g. Kröger i997; Le Bihan and Martin 2006). Answering such questions helped us to identify how different actors co-operate in such areas as public elder-care, family carers and help provided by profit and non-profit organisations. Such an approach also draws attention to the rationales that access to help and support from different sectors build upon (Rainwater, Rein and Schwartz I986).

The paper begins with an overview of structural differences between the two countries as a background to how care and support is organised. After a presentation of the methodology, we turn to the results of our case studies regarding our main questions: how did the older persons we interviewed get access to public help? Who are the actors in the care package she/he receives and how does the provision of care actually function? Do social and gender differences or inequalities exist in the way care is given and/or received? The second part of the paper examines the main steps in the setting up of the care provision. The third part considers recent changes in the organisation of elder-care in the two countries. Finally, we discuss the social and gender differences observed in the care actually received by the interviewed elderly persons. 


\section{Structural differences between Sweden and France}

\section{Distribution of responsibilities}

The role of the state in the distribution of responsibilities for social care is crucial (Daly and Lewis 2000; Esping-Andersen I990) and state intervention is identified to be much more important in Sweden than in France, where the family, voluntary organisations and the market play larger roles. Since the I950s, responsibilities and obligations between generations in Sweden are regulated through the welfare system (Millar and Warman I996). Before then, under the Poor Law the main responsibility for older generations lay with children, and the municipality stepped in only as a last resort. Although since I956 municipalities cannot charge children for the care costs of elderly parents, it was not until 1978 that all intergenerational legal obligations were removed. From this date marriage continues to regulate legally the relationship between spouses to some extent, while most other social rights are individualised (including pension rights). ${ }^{2}$ In Sweden, the degree of defamilialisation is high, which means that much of the care work is performed outside the family (Bambra 2007; Lister I990). Social services for children, elderly and disabled persons are financed through taxes and are to a large extent publicly organised and access to social benefits and services is based on citizenship rather than on previous labour market participation (Esping-Andersen Ig9o).

The official principle underlying the care of older people in Sweden is universalism and extensive coverage, and according to the Social Services Act benefits are related to needs rather than purchasing power (Regeringens proposition I997/98 : I I3). ${ }^{3}$ Although elder-care became a major national issue and a state responsibility in the I950 and ig6os, municipalities continue to hold the responsibility for its implementation, which in practice leads to large differences at the local level. Some researchers even use the concept of 'municipal welfare regimes' (Kröger 1997). Changes in the legal and economic frameworks in the I99os, together with the transfer of medical care for older people, disabled people and persons with psychiatric problems from the state to the local level have further increased municipal responsibilities.

In France, historically elder-care has been the main responsibility of the family and it still is in legal terms, as responsibilities between generations continue to be enshrined in civil law (Weber 2006). Over time, the responsibility for elder-care has increasingly become shared between the state (social assistance to those in need ${ }^{4}$ ), the insurance system (worklife-related pension schemes ${ }^{5}$, the social economy (mutual insurances and associations $^{\mathbf{6}}$ ) and the family. In contrast to public childcare policies that 
developed early in France, it was not until the Ig9os that eldercare policies were explicitly raised as a political issue.

In the I990s, a voucher system and tax deductions were introduced for eldercare-related jobs. The special benefit for dependency created in 1997 (Prestation Spécifique Dépendance, PSD) was replaced in 2002 by the allowance for personal autonomy (Allocation Personnalisée d'Autonomie, APA). The APA is managed at the regional (département) level. In one sense the benefit is considered universal as it is not connected to former worklife positions and work-life-related insurance. In contrast to the PSD which was related to wealth, the APA allowance cannot be claimed from the recipient's estate while both schemes are related to incomes. Due to increasing costs, a redefinition of the scheme is currently being discussed.

\section{Distributions of costs}

Social services in Sweden are mainly tax-financed (8o per cent paid by local taxes and 16 per cent by state grants) and only a minor part (4 per cent) of the cost for elder-care is covered by fees paid by the recipients themselves. Swedish elderly care is traditionally publicly organised and financed, but since the I9gos the proportion of other providers has been increasing and paid help purchased from the market is becoming more common (Szebehely I995, I998, 2000). In 2009, I I per cent of home care and I4 per cent of special housing was privately organised, although it is still publicly financed (The Swedish Association of Local Authorities and Regions 2009). In 2007, a tax deduction taking into account the costs of various kinds of home services was introduced, including services and help for elderly persons (Regeringens proposition 2006/07:94). As in France, this reform is part of a wider employment policy.

In France, more sectors contribute to the financing of care of the elderly than in Sweden (see Notes 5 and 6). Cash for care benefits, i.e. supported either with cash benefits or by tax deductions for buying services from different kinds of providers, are designed to allow older people to choose the type of care they need. Promoting care services for elderly people has also been part of an employment strategy. This strategy has been encouraged by different kinds of vouchers and the system has recently been simplified by the introduction of a universal voucher system (Chèque Emploi Service Universel, CESU). In 2008, I.4 million private employers used CESU to pay for such services (Agence Nationale des Services à la Personne 2008). Adjerad (2005) reports that 55 per cent of all privately paid domestic services involve assistance for elderly persons (including housework). 
In Sweden, the care of elderly people is a decentralised social service and its organisation depends largely on local municipal socio-political traditions, economic and political contexts (Trydegård 2000). There are large differences in the expenditure per capita for elder-care between municipalities, especially with regard to eldercare services for those living in ordinary housing. The interpretations of the national framework laws by the municipal social welfare board, as laid down in local objectives and regulations, and the actual implementation of these by the administrators who work with elder-care in their daily life, all influence the elder-care experienced by those in need of care and support (Thorslund 2002).

Starting in the I950s, the home help service was initially run by voluntary organisations, but their activities were successively taken over and expanded by the municipalities. The aim was to limit the number of old people's homes (residential homes) which carried heavy connotations of poverty and class differences. The first state grant introduced in the midI96os aimed at expanding home help services for elderly people. The organisation of the home help service meant that everyone irrespective of social background had the possibility to continue to live in their own homes (Thorslund 2002).

The municipalities, and to an increasing degree the private sector, provide home help services, such as cleaning, washing, shopping, etc. as well as social care. They also offer special housing, home medical services, meals on wheels, personal safety alarms, home adaptations and transportation services. The municipalities are responsible for supporting families, such as the provision of benefits to relatives giving home medical care and care allowances for home care, while economic benefits for family care providers, i.e. benefits replacing labour market participation, are handled by the local social insurance office. The municipalities further organise different kinds of relief for relatives, such as short-term care and daily activities for elderly persons.

In 2006, the proportion of persons in the age group 65-79 with public home help living in ordinary housing amounted to 3 per cent compared to 2I per cent among persons aged 80 or older. Among older people living in special housing, a decrease from 8 to 6 per cent has taken place since 2000 ; among the $80+$ age group the proportion has decreased from 20 to I6 per cent. Seventy per cent of those living in special housing are women.

In France too, the implementation of public elder-care relies both on the local (municipalitê) and regional level (département). However, the Ministry of Health decides a national rate of benefits and allowances, which is applied throughout the country, so it could be said that the decentralisation above 
all refers to the management of policy directed to older people. Depending on the level of dependency (see Note 9), the allowance for personal autonomy (APA) can be used for three types of help: housework (cleaning, ironing, etc.), personal services (washing, dressing) and technical equipment (wheelchair or bed, for example). The older person him/herself chooses to have such services delivered by persons and organisations providing services and/or care, very often non-profit organisations but also for-profit organisations. Many municipalities offer some services such as home help and delivery of meals, and the charges are means-tested.

Registered organisations intervening in the sector of human services are mainly non-profit organisations: associations (83 per cent) and municipal social welfare office (I2 per cent). Private enterprises are increasingly operating in the sector ( 5 per cent). Thirty-five per cent of the activity of private enterprises operating in the sector of human services concerns care and services for dependent elderly persons (Chol 2008). However, beside these organisations, a high proportion of the services for elderly care are provided on the basis of an individual relationship between an employer and an employee. It has been estimated that 36 per cent of the hours dedicated to home help for people aged 70 and more is delivered on an individual contractual basis, with the remainder delivered via organisations (Chardon and Estrade 2007, quoted in Conseil Emploi Revenus Cohésion sociale 2008: 87).

If we turn to publicly helped people, in 2008 one million received the APA benefit, 62 per cent of them continue to live in their homes while $3^{8}$ per cent are accommodated in special housing (in this case the benefit is delivered to the establishment) (Espagnol, Lo and Debout 2008). ${ }^{7}$ Women are the majority of the persons receiving the APA allowance (as they are the majority of the $65+$ ). In 200564 per cent of those aged $75+$ and 77 per cent of the $75+$ age group receiving APA were women (Perben 2006). ${ }^{8}$

In contrast to Sweden, where to a large extent social services are still organised by the municipalities and publicly provided, human services in France are offered at the local level by several providers. The level of the APA allowance is fixed at the national level in relation to the older person's medical needs and to her/his income while a uniform scale is missing in Sweden and variations are found between municipalities.

\section{Methodology}

The conditions structuring the older persons' experiences were analysed on the basis of secondary literature sources and a close reading of policy 
documents, legislation and reports from national agencies and authorities. The two case studies build on interviews with older people, administrators and relatives. Since the study was explorative, a limited number of persons were interviewed and only two geographical locations were chosen in each country. The older people interviewed had received social care in Sweden or received allowance for personal autonomy (APA) in France for a period between one and two years. Access was arranged with the help of administrators at the municipal social welfare board in Sweden and by social workers at the local authority (département) in France. The sample represents different household compositions, gender, class and geographical residence (urban/rural). The focus of the interviews was on life history, social contacts, current health status, care and service situation (formal and informal) as well as on how the planning of care and social services had taken place (Daune-Richard et al. 2008).

In Sweden ten single older people and six couples were interviewed. Two interviewees lived in special housing (two-room flats), one in a residential home and ig lived in their own homes (rented or owned). Thirteen of the interviewees were women and nine were men. The Swedish case study was situated in one rural and one urban municipality in the province of Skåne (South of Sweden). The French sample included 2i persons: I 2 singles, seven couples and two sisters living together. Ten of them lived in their own homes, nine in special housing and two in short-term housing for medical rehabilitation. Thirteen of the interviewees were women and eight were men. In France, the study was located in two large towns and several villages situated in the region (département) of the Bouches du Rhône (South of France). In Sweden, six adult children and four care managers were also interviewed separately, while adult children or relatives often attended the interviews in France. Six social workers and the head of the department responsible for APA at the regional board (Conseil général), i.e. the local authority of the region, were also interviewed separately. The results of the research (secondary literature review of policy documents and interviews) focus on three themes: assessment procedures, changes in the organisation of elder-care, and social and gender roles.

\section{Assessment procedure and access to public help}

There are large procedural differences in the assessment process between the two countries. In Sweden, access to social care is based on expressed needs, which are assessed by a care manager working at the municipal social welfare office. All decisions about support are taken by the municipally employed care manager, irrespective of whether services are delivered 
by public or private providers. As the municipal representative, the care manager is also the person most people meet when they apply for care and services. The care manager assesses the older person personally, sometimes at hospital, but mostly (either as a first meeting or as a part of a follow-up process) in their own home.

In France social care assessments largely take place within a medical framework, where the concept of dependency is paramount, although social considerations are progressively being taken into account. The dependency of older people used to be treated in the same way as that of disabled persons. The introduction of the special benefit for dependency (PSD) in 1997 made a break with the medical idea of dependency (Bigot and Rivard 2003) and introduced a distinction between aged persons' dependence and that of not aged adult persons with disabilities (Ennuyer 2003). The current allocation for personal autonomy (APA) depends on the assessment of the degree of dependency which is measured by a national scale (Autonomy, Gerontology, Groups: Autonomie Gérontologie Groupe Iso Resources, AGGIR). ${ }^{9}$ Ennuyer (2003) notes that this assessment procedure is more oriented towards 'what the person is not able to do' rather than to support his or her autonomy.

The request for an assessment (with an attestation by a doctor) is made to the local authority (Conseil général). The request is examined by administrative staff who can reject it. If not rejected it is examined by sociomedical staff and one of them (in our case study only doctors made the examination but in other local authorities it can be nurses or social workers) visits the older person to specify the level of dependency according to the grid. Once the grid is completed, the degree of dependency is attributed according to the six levels of APA. A qualified social worker from the local authority then visits the elderly person's home, draws up a 'care plan' and provides a list of services. Along with the principle of 'free choice', it is up to the older person to choose the provider and make contact.

As noted above, in Sweden there is usually only one designated person - the care manager - that oversees the assessment process. In France, the procedure is often a complicated process. Some of the older people had difficulties making contact with the allocated social worker as she was only available one half-day a month. Home adaptations often took a long time and involved complex administrative procedures. In the region (département) concerned, the assessment process usually takes up to two months, and there is no fast-track procedure (procédure d'urgence) of the kind available in other regions. The slow process often means that families have to organise help and/or home adaptations themselves (at their own expense) before the APA plan is implemented. 
Sweden has a comparatively transparent system in place since the ig6os and the role of the care manager was strengthened during the rggos. The existence of the local social welfare office and the role of the care manager are generally well-known to the public. The assessment of needs is always made by care managers at the local social welfare office irrespective of whether it is publicy or privately organised. The more uniform organisation of elder-care as well as a relatively limited number of actors facilitates contacts between elder-care and older people. ${ }^{\mathbf{1 0}}$

Most of the interviewed Swedish elderly persons had come into contact with the eldercare system after being hospitalised or being ill. The route to home help often goes through the medical system. A care plan is then made at the hospital with the attendance of a care manager, an occupational and/or physical therapist as well as adult children or other relatives. An elderly couple where the wife was severely disabled after a stroke told us about how care was arranged for them 'Yes, it [home adaptations] was all arranged from the start. We have been in continuous contact with the occupational therapist.... They built a slope outside the house so we could easily reach it by wheel-chair. ... and a bed and a chair to put in the bathtub'. Some of the interviewees had been informed about available support on the initiative of the care managers simply on account of their advanced age. Others were already familiar with the system as their spouses were receiving or had previously received home help. They knew the care manager quite well, referred to them by their name and knew how to contact them when their needs changed and a new assessment had to be made. Only a few of the elderly French persons had likewise been helped to apply for the APA allowance while hospitalised, but the initiative was more often taken by adult children, nieces or friends. And the co-ordination between hospital and/or rehabilitation centre and the implementation of the APA care plan was an exception. A women of 85 who was severely disabled and who had been hospitalised for a month told us that no measures had been taken for her return home the next day although the hospital knew about her situation. 'They have not suggested anything although they know I am not able to walk. They just cannot send me directly back home!' The French interviewees simply had to rely on children, relatives or neighbours to arrange their care.

The system of cash for care in France appears to be difficult for older people and their relatives to understand. In order to improve this, municipal centres for information and co-ordination (Centre local d'information et de coordination, CLIC) were established in 200 I to help families. Sometimes a social worker takes the lead in arranging care and services, but family members or friends play the most crucial role. From a Swedish point of 
view, the French system of elder-care is fragmented in provision as well as in financing.

\section{Recent changes in the organisation of elder-care - implications for older people}

The role of the state is crucial in the identification of changes in the organisation of social care and the relationships between caregivers and care recipients (Daly and Lewis 2000). The historical background of welfare systems also means different attitudes towards state responsibility and intervention, involving different patterns of values and norms relating to family responsibilities and gender roles. Western European welfare states are in different stages of the 'defamilialisation' process, i.e. to what extent it is becoming legitimate to externalise caring functions traditionally confined to the family and women (Bambra 2007; Lister 1990).

\section{Defamilialisation - refamilialisation?}

In Sweden, the removal of formal obligations between family members has implied a change in the relationship between the individual and the state (Antman I996). However, some obligations still exist between spouses according to marriage law (see Note 2). The idea of defamilialisation of social services within elder-care (as well as child-care) is still prevalent, implying that the responsibility for the care of elderly persons rests upon public authorities, and it means that individuals have the right to public help and support and that the costs are covered by taxes. However, recent studies point to an increasing amount of help and support being performed by family members (Rauch 2007; Sand 2004; Szebehely I998, 2000). A study conducted by the National Board of Health and Welfare on home help in ordinary housing also showed that means-testing is taking place and an increasing number are buying help from the market (Socialstyrelsen 2004). Both are contradictory to the official goals of eldercare.

The increase in informal help and support from family members implies a change in public eldercare policy in Sweden. Starting in the 1950s and Ig6os, the care of older people in their own homes was prioritised at the same time as the number of places in special housing was reduced. Consequently, the number of persons in need of extensive care and services living in their own homes increased, and home help became more and more targeted. The targeting of those in need made less home help available for older people with less acute needs. As a consequence the 
latter group has increasingly become reliant on informal help or help purchased from the market.

Simultaneously, budgetary restrictions have led to a decrease in the number of hospital beds and the length of stay. At the same time, the number of persons over 8o increased by 22 per cent from 1992 until 2003 (Larsson and Szebehely 2006). Thus a large number of elderly persons with care, service and medical needs continue living in their own homes, with consequences for the working conditions of home helpers and the organisation of home medical services.

In France, the responsibility for the care of frail elderly people is traditionally shared between public providers, the insurance system, the social economy and the family. The vision of a national policy for older people formulated in the Laroque Report in the ig6os was not realised until the end of the r99os. In the legislation that set up the APA in 200I, elder-care is for the first time formulated as a universal right eligible to those in need of practical help with their everyday life. To conclude, the APA is a universal, but means-tested right. It seems as though many people with higher incomes do not claim it, but on the other hand they use tax deduction incentives to purchase human services. Elder-care in France, however, is not yet fully individualised or defamilialised (Bambra 2007; Lister 1990). Intergenerational obligations are still prescribed under civil law (Weber 2006). Knowledge about the APA allowance seems to be limited and morally and politically the family continues to be publicly supported ( $c f$. the 2006 Conférence de la Famille below).

Since the I99os, the role of the state has decreased in Sweden while it has increased in France, although in France the family continues to play a crucial role. The introduction of the APA allowance has not decreased the support given by family members: the amount of care provided by the family (mainly women) is twice as much as the care provided by professional home helpers (Rivard 2006). In 2006, the Family Conference (Conférence de la Famille) proposed measures to support carers. Since January 2007, family carers of disabled relatives are eligible for three months of 'family support leave' (congé de soutien familial) that can be extended up to one year. This leave was unpaid until March 2010 when a special allowance for terminal care was introduced (Allocation journalière d'accompagnement d'une personne en fin de vie). Additionally, family carers can validate their care experience as 'professional experience', allowing them to shift towards social care jobs.

Since the late I990s, the Swedish government has developed centres for relatives, established key workers to support carers, improved the efficiency of organisations and information, and developed day activities and short-term housing. However, financial support for carers (as a 
replacement for labour market participation) has decreased (The Swedish Association of Local Authorities and Regions 2006). Defamilialisation is still a cornerstone of the Swedish public eldercare policy, while in practice trends towards refamilialisation or at least informalisation have emerged. In France, public eldercare policy supports defamilisation to some extent through the APA system. At the same time the role of the family is supported both institutionally and economically.

\section{Marketisation}

As discussed above, in France, elder-care is currently organised along cash for care lines. The supply of paid services is organised either as a direct relationship between the client and the employed person who cares for his/ her needs, or by organisations, traditionally associations or public providers such as the municipal social welfare office (Centre Communal d'Action Sociale, CAAS). Since I996, private companies can provide services, and although their numbers are still limited it should be noted that there has been a sharp increase since 2005. The introduction of different voucher systems has stimulated the market for human service jobs. The French situation can be described as a care system that is very much organised along market principles. At the same time it is controlled by rules and regulations. The system of cash for care is very clearly related to a labour market made up of staff with low qualifications and poor working conditions.

In Sweden, the main trend is rather towards informalisation and refamilialisation (Szebehely 1998) and the marketisation of social care workers is still limited and regulated. Public providers still largely exceed the number of private providers and the municipality is still responsible for quality control. However, the market provision of social care has increased for elderly persons who are not targeted as most in need. The introduction of tax reductions for household and human services in 2007 has also stimulated the market sector.

A summary of the development in the two countries shows that the marketisation of elder-care plays an important role in French eldercare policy, partly because it is incorporated in a more general labour market strategy, while in Sweden marketisation is still relatively limited and is subject to public control.

\section{The implementation of elder-care: social and gendered differentiations}

The majority of older people who were interviewed in France and Sweden did not seem to be isolated from their families. Nevertheless, in France the 
family plays a much more crucial and necessary role during the process of accessing services, while in Sweden the family appears as something extra, a 'plus' in this process. In Sweden, although adult children attended care plan meetings, the priority was the elderly person's needs and not the family's needs or expectations. In France adult children, relatives and friends provided more practical help. Older people living alone in Sweden did not experience the problems encountered by those living alone in France. The French system only seems to function properly if the older people are supported by their family. Older people in France with low incomes seemed to have larger problems of managing everyday life and also more difficulties accessing the APA allowance. Moreover, the lengthy process of applying for the APA allowance meant that some people had to pay for private help in the interim period or beyond if they were deemed not eligible.

These inequalities in France are also gendered, as carers are mostly women: above all spouses but also daughters, nieces, granddaughters, etc. Responsibility for family care was often seen as 'natural' for women, whether they were family members or professionals. However, as reported in previous research, expectations can also be placed on adult children in Sweden (Sand 2004; Szebehely 2000). One daughter told us that when her mother announced that she did not like the pre-packed food delivered for a whole week at a time,

then somebody had told her that if she had a daughter, then the daughter could cook for her and put the meals in the freezer. But my mother told them that her daughter was working and had a family of her own. ... Or to go to the doctor etc. and then my mother tells them that her children work and cannot take breaks.

In Sweden, as in France, differences in access to care exist according to income. People with higher incomes tend to pay for services (primarily cleaning and gardening) and continue to do so when getting older, without feeling that this professional help was an intrusion. But in France workingclass women usually organise and do the caring and, in our case study, they tended to feel that help from outside the family was an intrusion. One of the female interviewees who together with her brother and sisterin-law was taking care of three dependent elderly relatives in her home told us :

There are many elderly persons who do not accept cleaning help, as they are not always so good. ... It the same with the meals, they are not always so good. That is why I don't want anybody and I have organised it together with my sisterin-law.

In more affluent families French women take the role only of an organiser, in a way similar to that of the care manager in Sweden. And, according to 
Da Roit, Le Bihan and Österle (2007: 668), 'the system has strengthened the role of informal carers as "care managers"'. Close links exist in France between the formal provision of care and the mobilisation of women, especially in the older person's entourage. In Sweden, with the exception of some families from lower social class groups, older people seldom rely on family members or friends for practical help. Intergenerational cohabitation hardly exists in Sweden, and the risk of isolation following widowhood or divorce is compensated by 'help at a distance'. A European study shows that in France, almost half of daughters of lone parents compared to one in four sons have reported that they help their older parent living alone, while in Sweden the figures for sons were close to those for daughters (Fontaine, Gramain and Wittwer 2007: I05).

In both case studies, we found a traditional gender division in the type of help given by children; sons take care of the garden, help to repair things in the house, take care of financial issues and the like, while daughters help to buy clothes and do other kinds of shopping as well as taking care of the laundry and preparing meals. But we also found that gender differences were less marked in Sweden than in France, especially among couples in need of social care. Most of the interviewed Swedish couples remained living in their homes and managed with public home help services irrespective of whether it was the man or the woman who became dependent. Men in couples with a dependent spouse often helped them as a complement to public home help. They told us about how they did the shopping, cooking, cleaning dishes, the laundry and the extra cleaning that was not included in the care plan. 'I am the homehelper of my wife in addition to the help we get from the municipality. I am the one who cooks, cleans and makes the laundry' (Man, 85, living at home with his disabled wife). Many women in the Swedish interviews used to have a paid job, which could mean that sharing household chores within the couple had been commonplace for a long time. However, in couples where the disabled woman had never done paid work, men also became increasingly responsible for domestic tasks. The fact that the interviewed daughters (reflecting national trends) were mostly in paid work might explain why family help is less gendered in Sweden.

In contrast, in France, whether or not to stay living in their own home was very much dependent on whether it was the man or the woman who became dependent. The spouse more often took care of a dependent man than vice versa. Also when males received help to care for their spouses, they often reported difficulties in taking care of the house and as a solution both of them moved to special housing. 


\section{Concluding remarks: Who helps whom with what and under what conditions?}

Following Rainwater, Rein and Schwartz (I986), claims for support from the state or the public system are based on needs and build on the presumption that society has a moral obligation to support its older members. This principle is embedded in legislation and social policy. The rationale for providing social care through the public domain differs from claims made on the family or the market. Claims on the family build on filial obligations, emotions, blood relationships, social customs and so on, and are negotiated in a personal manner. Claims on the market are based on economic principles, i.e. help is given provided it is paid for.

According to the Swedish welfare tradition, access to public support is based on needs, and no consideration should be given to the extent to which help could be given by family or to the older person's own economic resources. The claims towards the public system come as rights, and according to the official eldercare policy expressed in legislation they should be individually assessed. However, the rather vague formulations within the legislation of how this principle should be applied, together with decentralised municipal policies for the provision of elder-care, give rise to 'considerable discretion as regards their [municipalities'] admission procedures. This discretion allows them to apply criteria of physical and practical needs but also financial and family related criteria to exclude service applicants from admission' (Rauch 2006: 294). Recent studies of elder-care confirm these trends counteracting the goals of the official eldercare policy (Sand 2004; Szebehely 2000). The two trends of informalisation and marketisation are contradictory to the idea of universal access to social services and the principle that home help from the public system is an individual right. A decrease in publicly assisted elder-care has led to an increase in family support with consequence for older people and their relatives. A survey undertaken by the Swedish National Board of Health and Welfare found that only one in ten women want to be helped by a relative to take showers, while one-third of them actually are helped this way, and although only one in ten women want to be helped by relatives with the laundry, half of them actually are (Szebehely and Ullmanen 2008). The goal of integrity, which is a cornerstone in the Swedish public eldercare policy, is thus not fulfilled for large groups of older people.

In France, despite the increasing responsibility of the state in elder-care since the end of the Iggos and especially since the introduction of the APA allowance in 200I, the main responsibility for the social care of older people still lies with the family. The public system contributes to cover 
costs for the payment for help from a range of different providers (although often only part of them) through the APA system, while it still mostly relies on the family to arrange access to public help, to co-ordinate the help from different providers - public and private - and to compensate for the deficiencies of public help (practically and financially). ${ }^{\mathbf{1 1}}$

Following Rainwater, Rein and Schwartz (I986), there is a clear difference between the two countries with regard to where the responsibility for elder-care are directed and discussed in society. In France the main responsibility is directed towards the family. Although claims towards the family are increasing in Sweden, they differ from those currently made in France. In France, recourse to the family as social carers takes the form of obligations under civil law, supported ideologically and institutionally at the political level. Family carers of older people are not simply the consequence of insufficient resources.

Cash for care gives the market a more prominent position in France than in Sweden, where help from the market is still publicly controlled with regard to costs and quality. Private companies work under fixed rules and still make up a minor part of eldercare providers. In France, elder-care is organised according to market principles and human services are bought from the market from different providers at different prices and with varying degrees of quality. The logic behind the market is that services can only be provided as long as they are paid for, whether this payment is private or public.

The market principle leads in reality to large variations in price and quality. Although public financial support for social care needs exists, working conditions for those directly employed by the elderly person are unregulated and the payment for human service jobs is generally low. The principle of 'free choice' in reality increases inequalities in access to human services of a high quality.

As discussed above, results from a range of studies in Sweden have shown that the reality of universal access to elder-care is questionable. Differences exist in eligibility procedures between municipalities, family members can be seen as substitute or complementary carers to the formal system, and assessments that take into account the financial situation of older people in need lead to a situation which presents some similarities to France. In our case studies of the process of accessing social care, however, we found that there are still large differences between the two countries, at the policy level as well as in everyday experiences. In Sweden, social care provided through the public system is still experienced as an individual right, most clearly expressed as demands made by adult children and as expectations of services for older persons in need of care. In France, the family remains the main provider, as access to social care through the 
public system is a complex process for both older people and their relatives and the public sector covers only part of their needs. The interviews show that family members in France, whether helped financially by the state or not, continue to take responsibility for providing help and support as well as responsibility for co-ordinating the different actors in the human service market. According to our findings, access to elder-care in the two countries still depends on criteria such as living arrangements, gender and social class, but inequalities in the provision of care along these lines are much more pronounced in France than in Sweden.

\section{NOTES}

I The project 'Les trajectoires d'entrée en dépendance des personnes âgées du point de vue du care: Approche comparative France-Suède' (Trajectories of Entry into Dependence from the Point of View of Care: A Comparative Study of Elder-care in France and Sweden) was financed by DRESS-MIRE at the French Health Ministry (Ministère de la Santé) and directed by Anne-Marie Daune-Richard (GNRS). It was conducted in France by Anne-Marie Daune-Richard (CNRS) and Sophie Odena with the contribution of Francesca Petrella (Université de la Méditerranée) at LEST (Laboratoire d'Economie et Sociologie du Travail), and in Sweden by Ingrid Jönsson and Magnus Ring at Lund University.

2 According to Johansson and Sundström (I996: 15) married persons have legal obligations to support their partners, although this officially does not include 'heavy' personal care. If so it falls under the responsibility of the Social Services Act.

3 In addition to the Social Services Act, other framework laws such as the Occupational Safety and Health Act, the Act on Health Services and the Act Concerning Support and Services for Persons with Certain Functional Impairments belong to the legal framework surrounding the national policy for elder-care.

4 In the i940s and I950s, an 'allowance for the elderly' (allocation spéciale vieillesse) and an 'allowance for mothers' (allocation aux mères de famille) were created for poor older people who were not included in the pension scheme, and in 1956 a supplementary allowance (minimum vieillesse) was introduced to guarantee a minimum living standard for all older people.

5 The French retirement system is mainly made up of statutory schemes accounting for about 9o per cent of total pension expenditures and financed by social security contributions and taxes. The functioning of these schemes varies along with economic sectors. The general scheme cohabits with statutory supplementary schemes established by collective agreements and pay-as-you-go financed arrangements in which benefits are calculated on the bases of a point system ensuring close links between contributions and benefits.

6 Mutual benefit organisations (mutuelles) supplement the national health-care system and reimburse part of the medical expenses that are not met by the national health insurance. Most of them provide services and accommodation for dependent elderly members and thus contribute to the eldercare system.

7 According to Espagnol, Lo and Debout (2008), the APA benefit covers on average 67 per cent of the dependence expenses for people living in establishments.

8 No data on the gender distribution are available since 2006 .

9 This grid has been used all over the country since 1997 to evaluate the loss of autonomy among persons aged $60+$. It defines six levels of dependency and determines 
the services and financial support related to each. Applications for the allowance for autonomy can be granted for the four most severe levels (I to 4).

Io Freedom of choice between public and private providers was introduced in 2009. Decisions about help are still taken by the municipal care manager who now also has the role of giving information about existing alternatives of choice.

II The average monthly amount paid out in 2008 was 504 Euros which is half of the minimum wage (Espagnol, Lo and Debout 2008).

\section{References}

Adjerad, S. 2005. Le secteur des emplois familiaux en 2003: la croissance de l'activité se poursuit [The sector of family employment in 2003: continued growth of employment]. Premières Synthèses Informations, I 2, 4, I-6. Dares, Ministère de l'Emploi, Paris.

Agence Nationale des Services à la Personne 2008. Available online at www. servicealapersonne.gouv.fr [Accessed I November 2009].

Antman, P. 1996. Barn- och äldreomsorg $i$ Tyskland och Sverige: Sverigedelen. Välfärdsprojektet, 5 [Child- and Elder-care in Germany and Sweden: The Swedish Part. The Welfare Project]. Socialdepartementet, Stockholm.

Bambra, C. 2007. Defamilisation and welfare state regimes: a cluster analysis. International Journal of Social Welfare, $\mathbf{1 6}$, 4, 326-38.

Bigot, F. and Rivard, T. 2003. L'évolution des modes de prise en charge et des métiers de la dépendance [Facing dependency: changes in occupations and models of undertaking care]. In Martin, C. (ed.), La dépendance des personnes âgées: Quelles politiques en Europe? [The Dependence of Older Persons: European Politics]. Presse Universitaires de Rennes, ENSP, Rennes, France, $157-74$.

Chardon, M.-A. and Estrade, O. 2007. Les métiers en 2015: Rapport du groupe prospective des métiers et qualifications [Occupations in 2015: A Report on Future Occupations and Qualifications]. CAS et Dares, La Documentation française, Paris.

Chol, A. 2008. Les services à la personne en 2006: une croissance continue [Human services in 2006: continued growth]. Premières Synthèses Informations, 48, 2, I-8. Dares, Ministère de l'Emploi, Paris.

Conseil Emploi Revenus Cohésion sociale [Council for Employment, Incomes and Social Cohesion]. 2008. Les services à la personne. La documentation française. Human Services, Paris.

Da Roit, B., Le Bihan, B. and Österle, A. 2007. Long-term care policies in Italy, Austria and France: variations in cash-for-care schemes. Social Policy and Administration, 4r, 6, 653-7I.

Daly, M. and Lewis, J. 2000. The concept of social care and the analysis of contemporary welfare states. British Fournal of Sociology, 5I I, 2, 28I-98.

Daune-Richard, A.-M., Jönsson, I., Odena, S., Ring, M. with Petrella, F. 2008. Les trajectoires d'entrée en dépendance des personnes âgées du point de vue du «Care»: Approche comparative France-Suède [Trajectories of Entry into Dependence from the Point of View of Care: A Comparative Study of Elder-care in France and Sweden]. Final report for DRESS-MIRE, Ministère de la Santé, July. Laboratoire d'Economie et de Sociologie du Travail, CNRS-Université d'Aix-Marseille, France.

Ennuyer, B. 2003. Histoire d'une catégorie 'personne âgées dépendantes' [The history of the category of dependent elderly persons]. In Martin, C. (ed.), La dépendance des personnes âgées: Quelles politiques en Europe? [The Dependence of Elderly Persons: European Politics]. Presses Universitaires de Rennes, ENSP, Rennes, France, 95-II4.

Espagnol, P., Lo, S.-H. and Debout, C. 2008. L'allocation personnalisée d'autonomie et la prestation de compensation handicap au 30 juin 2008 [The Allowances for Personal 
Autonomy and Handicapped Persons of 3o June 2008]. Etudes et résultats, 666, I-6. Dress, Ministère de la Santé, Paris.

Esping-Andersen, G. 1990. The Three Worlds of Welfare Capitalism. Polity Press, Cambridge.

Fontaine, R., Gramain, A. and Wittwer, J. 2007. Les configurations d'aide familiales mobilisées autour des personnes âgées dépendantes en Europe [Family help mobilised around elderly dependent persons in Europe]. Economie et statistique, 403/4, 97-II5.

Johansson, L. and Sundström, G. 2006. Policies and practices in support of family caregivers - filial obligations redefined in Sweden. Fournal of Aging \& Social Policy, r 8, 3/4, 7-26.

Kröger, T. 1997. Local government in Scandinavia: autonomous or integrated into the welfare state. In Sipilää, J. (eds), Social Care Services: The Key to the Scandinavian Welfare Model. Avebury, Aldershot, UK, 95-108.

Larsson, K. and Szebehely, M. 2006. Äldreomsorgens förändringar under de senaste decennierna. Äldres levnadsförhållanden: Arbete, ekonomi, hälsa och sociala nätverk 1980-2003 [Changes in Eldercare in Recent Decades. Living Conditions Among Older People: Work, Economy, Health and Social Networks 1980-2003]. SCB, Stockholm, 4I I-20.

Le Bihan, B. and Martin, C. 2006. A comparative case study of care systems for frail elderly people: Germany, Spain, France, Italy, United Kingdom and Sweden. Social Policy and Public Administration, 4o, I, 26-46.

Lister, R. 1990. Women, economic dependency and citizenship. Fournal of Social Policy, r 9 , $4,28 \mathrm{I}-98$.

Millar, J. and Warman, A. 1996. Family Obligations in Europe. Family Policy Studies Centre, London.

Perben, M. 2006. L'allocation personnalisée d'autonomie au 31 décembre 2005 [The allowance for personal autonomy, 3I December 2005]. Etudes et résultats, 477, March, I- 4 .

Rainwater, L., Rein, M. and Schwartz, J. 1986. Income Packaging in the Welfare State: A Comparative Study of Family Income. Clarendon Press, Oxford.

Rauch, D. 2006. Institutional fragmentation, institutional engineering and the development of elderlycare and childcare in Sweden. Scandinavian Political Studies, 29, 4, 285-307.

Rauch, D. 2007. Is there really a Scandinavian social service model? A comparison of childcare and elderly care in six European countries. Acta Sociologica, 5o, 3, 249-69.

Regeringens proposition 1997/98: I13. Nationell handlingsplan for äldrepolitiken [Governmental proposal for a national action plan for elderly policy], April 1998. Socialdepartementet, Stockholm.

Regeringens proposition 2006/o7:94. Skattelättnader för hushållstjänster, m.m. [Governmental proposal for tax deduction for household services, etc.], 4 April 2007. Finansdepartementet, Stockholm.

Rivard, T. 2006. Les services d'aide à domicile dans le contexte de l'allocation personnalisée d'autonomie [Household services in the context of the allowance for personal autonomy]. Etudes et résultats, 46o, I-IO. Dress, Ministère de la Santé, Paris.

Sand, A.-B. 2004. Förändrad tillämpning av offentlig äldreomsorg-ett hot mot målsättningen om demokrati och jämställdhet [Changes in public elder-care - a threat towards democracy and equality]. Socialvetenskaplig tidskrift, 3/4, 293-309.

Socialstyrelsen. 2004. Vard och omsorg om äldre [Care of the Elderly]. Socialstyrelsen, Stockholm.

Szebehely, M. I995. Vardagens organisering: Om vårdnadsbiträden och gamla $i$ hemtjänsten [The Organisation of Everyday Life: On Home Helpers and Older People in Sweden]. Arkiv Förlag, Lund, Sweden.

Szebehely, M. 1998. Changing divisions of carework: caring for children and frail elderly people in Sweden. In Lewis, J. (ed.), Gender, Social Care and Welfare Restructuring in Europe. Ashgate, Aldershot, UK, 257-83. 
Szebehely, M. 200o. Äldreomsorg i förändring-knappare resurser och nya organisationsformer [Changes in elder-care - scarce resources and new organisational forms]. In Szebehely, M. (ed.), Välfärd, vård och omsorg. Forskarantologi från Kommittén Välfärdsbokslutet [Welfare and Care. A Research Anthology from the Welfare Commission]. SOU 2000:38, Socialdepartementet, Stockholm, I7I-225.

Szebehely, M. and Ullmanen, P. 2008. Vård av anhöriga - ett högt pris för kvinnor [Care of relatives - at a high price for women]. Välfärd, 2, 12-4.

The Swedish Association of Local Authorities and Regions 2006. Care of the Elderly in Sweden Today. The Swedish Association of Local Authorities and Regions, Stockholm.

The Swedish Association of Local Authorities and Regions 2009. Developments in Elderly Policy in Sweden. The Swedish Association of Local Authorities and Regions, Stockholm.

Thorslund, M. 2002. Dagens och morgondagens vård och omsorg [Today's and tomorrow's care of older people]. In Andersson, L. (ed.), Socialgerontologi [Social Gerontology]. Studentlitteratur, Lund, Sweden, $23{ }^{-5}{ }^{2}$.

Trydegård, G.-B. 2000. Tradition, Change and Variation: Past and Present Trends in Public Old-age Care. Department of Social Work, Stockholm University, Stockholm.

Weber, F. 2006. Reconnaitre les aidants familiaux [Recognition of family helpers]. Connaissance de l'emploi, 34, September, I-4. Centre d'Etudes de l'Emploi, Paris.

Address for correspondence:

Ingrid Jönsson, Department of Sociology, Lund University, Box II4 SE 22I oo, Paradisg. 5:G, Lund, Sweden.

E-mail: Ingrid.Jonsson@soc.lu.se

\section{СамвRIDGE JDURALS}

